\title{
GovernanÇa Global DA TRIBUTAÇÃO E OS TRATADOS INTERNACIONAIS DE COOPERAÇÃO E TRANSPARÊNCIA FISCAL
}

\author{
Alceu Mauricio Junior*
}

\begin{abstract}
1 Introdução. 2 A globalização e os desafios à tributação do capital internacional. 3 Elisão, evasão e planejamento fiscal abusivo no plano internacional. 4 Os instrumentos de governança global da tributação. 4.1 Tratados relacionados ao Foreign Account Tax Compliance Act (FATCA). $4.2 \mathrm{O}$ projeto sobre a erosão de bases imponíveis e traslado de lucros (BEPS). 5 Os tratados de cooperação internacional podem violar direitos humanos?. 6 Considerações finais. Referências.
\end{abstract}

\section{RESUMO}

Este trabalho objetiva analisar os novos instrumentos de governança global da tributação e a controvérsia sobre a possível inconstitucionalidade das normas domésticas que implementam tratados fiscais internacionais de cooperação e troca automática de informações. O trabalho aborda os impactos da globalização sobre os sistemas tributários, apontando que a mobilidade do capital internacional e a ausência de mecanismos eficientes e transparentes de cooperação e troca de informações fiscais facilitam a evasão fiscal e o planejamento tributário agressivo. Sistemas fiscais domésticos isolados e não coordenados não são capazes de apresentar resposta adequada a esses efeitos indesejados, e, consequentemente, os Estados perdem sua capacidade de financiar a efetivação dos direitos humanos. Nesse cenário, surge um novo paradigma de governança global da tributação e do Direito Fiscal Internacional, que volta sua atenção para os problemas da evasão fiscal e da erosão das bases imponíveis. Partindo dessas premissas, este artigo apresenta dois instrumentos de governança global da tributação - os tratados relativos ao FATCA e a Ação 12 do Projeto BEPS. Por fim, investiga-se a possível violação de direitos de privacidade e de livre iniciativa em razão da implementação desses instrumentos internacionais na ordem jurídica nacional, efetuando-se uma análise a partir de precedentes do Supremo Tribunal Federal e do direito comparado. Conclui-se que a implementação de tratados internacionais para cooperação e transparência fiscal não é prima facie inconstitucional, embora gere maiores responsabilidades às autoridades tributárias no que tange à preservação dos direitos dos contribuintes.

Palavras-chave: Direito Fiscal Internacional. Direito Constitucional. Cooperação Fiscal Internacional. Privacidade. Liberdade de Iniciativa.

* Doutor em Direito Constitucional e Teoria do Estado pela Pontifícia Universidade Católica do Rio de Janeiro. Mestre em Direito Público pela Universidade do Estado do Rio de Janeiro. Docente do Curso de Graduação em Direito e do Mestrado em Sociologia Política da Universidade Vila Velha, Vila Velha-ES, Brasil. Juiz Federal em Vitória-ES, Brasil. E-mail: <alceu.mauricio@gmail.com>. https://orcid.org/0000-0002-0521-7394 


\section{INTRODUÇÃO}

Em fevereiro de 2015, o mercado financeiro internacional e o público ao redor do mundo foram abalados pela revelação do escândalo conhecido por "Swiss Leaks", por meio do qual se tomou conhecimento das atividades de fraude e evasão fiscal realizadas por intermédio da filial do banco HSBC na Suíça. As investigações indicaram que "entre 9 de novembro de 2006 e 31 de março de 2007, 180,6 bilhões de euros passaram por contas detidas por mais de 100 mil clientes e 20 mil empresas offshore com o HSBC em Genebra." (DAVET; LHOMME; MICHEL, 2015, online). O escândalo do HSBC impressionou pelo volume e pela organização institucional das operações desse esquema, mas o problema subjacente que o tornou possível - a falta de transparência fiscal - já era bem conhecido.

As transformações tecnológicas e a globalização experimentadas nas últimas décadas permitiram grandes avanços no comércio e no mercado de capitais internacionais, mas, por outro lado, tornaram possíveis fraudes e evasões fiscais por meio de contas offshore e esquemas de planejamento fiscal agressivo que se sustentam em práticas nocivas de competição fiscal e na falta de transparência e articulação entre as autoridades fiscais nacionais, enfraquecendo a capacidade dos Estados de promover os direitos humanos e as prestações do Estado social.

A política tributária de base nacional, tradicionalmente arraigada ao modelo westfaliano como típica manifestação da soberania do Estado, passou a não ser suficiente para lidar com fenômenos que se estendiam além de seu território. Renovou-se, assim, a necessidade de construir-se uma verdadeira governança global da tributação, na qual os países possam criar mecanismos de cooperação e transparência fiscal, de modo a inibir práticas criminosas ou danosas à sustentação fiscal dos Estados.

Para dar suporte jurídico a essa governança global da tributação, constrói-se um novo Direito Fiscal Internacional, ${ }^{1}$ que não se limita a evitar a dupla tributação, mas também busca criar instrumentos legais para conter a evasão fiscal e a erosão das bases imponíveis. No entanto, como se estruturam esses novos instrumentos de governança global da tributação? Esses novos desdobramentos do Direito Internacional e suas repercussões nos sistemas fiscais nacionais, projetados para fortalecer as bases imponíveis dos Estados e permitir a promoção dos direitos humanos e do Estado social, também podem colocar em risco os direitos de privacidade e livre iniciativa?

Neste trabalho, procuramos enfrentar essas questões e delinear esse novo paradigma de governança global da tributação, tomando como foco os tratados internacionais de cooperação tributária para troca de informações e transparência fiscal. Para tanto, exploramos inicialmente as transformações e os desafios colocados pela globalização à tributação do capital internacional, indicando que, embora a globalização tenha viabilizado uma dinâmica sem precedentes nos fluxos de capital ao redor do mundo, provocou impactos negativos sobre a tributação dos países ao facilitar esquemas de evasão fiscal e redução de bases imponíveis. Em seguida, analisamos com maior detalhe a elisão, a evasão fiscal e o planejamento fiscal 
abusivo no plano internacional, expondo como essas práticas encontram campo fértil em um ambiente de opacidade fiscal e não cooperação entre os Estados. Essa análise nos leva ao estudo dos instrumentos de governança global da tributação, especialmente os tratados relacionados ao FATCA (Foreign Account Tax Compliance Act) e à Ação 12 do Projeto sobre a Erosão de Bases Imponíveis e Traslado de Lucros (BEPS). Por fim, abordamos o questionamento relativo à possível violação de direitos humanos por ações decorrentes de tratados de cooperação fiscal internacional, efetuando uma análise a partir de precedentes do Supremo Tribunal Federal e do direito comparado.

\section{A GLOBALIZAÇÃO E OS DESAFIOS À TRIBUTAÇÃO DO CAPITAL IN- TERNACIONAL}

Embora o comércio internacional e o trânsito de pessoas e de mercadorias entre países possam remontar à antiguidade, na segunda década do século XX e na transição para o século XXI, consolidou-se o fenômeno que tem sido denominado globalização. A globalização não significa apenas uma maior intensidade no fluxo de pessoas e de mercadorias entre os países, mas também a criação de novas dimensões e estruturas que não eram possíveis antes da revolução tecnológica que ocorreu nos últimos cinquenta anos. Não apenas mercadorias e produtos são vendidos no mercado internacional, mas também as próprias cadeias de produção passaram a ser formadas por redes multinacionais, conectadas por sofisticados sistemas de logística, tornando rótulos de nacionalidade ilusórios. Corporações transnacionais adquiriram a capacidade de exportar empregos para os países onde condições institucionais e jurídicas lhes fossem mais favoráveis, especialmente quanto a regulações ambientais e trabalhistas. Turbinado pelo avanço nos sistemas de comunicação e informação telemática, o fluxo de capitais libertou-se das amarras dos meios físicos de transportes de valores. A globalização trouxe ao capital uma mobilidade sem precedentes, permitindo-lhe assumir um caráter supranacional, com impactos não somente econômicos. Os abalos provocados pela globalização foram sentidos nos sistemas políticos, jurídicos e culturais, ou seja, nas próprias bases do modelo de Estado-nação que se consolidara desde a Paz de Westphalia, provocando, por outro lado, reações de "re-nacionalização" vindas de ambos os polos do leque político. Como resultado, o capital supranacional adquiriu o poder de colocar os países - desenvolvidos e subdesenvolvidos - em uma competição por investimentos, tendo por parâmetros infraestrutura, menores exigências regulatórias e, também, menores cargas tributárias. ${ }^{2}$ Dessa forma, o capital passou a poder escolher - por si só, sem maiores interferências de sistemas políticos e jurídicos nacionais seus domicílios de investimento, de produção e, sobretudo, seu domicílio fiscal (BECK, 2000).

Outro aspecto não menos relevante da globalização é a diferença na mobilização observada entre o capital e o trabalho. Após o período que se estendeu do final do século XIX ao início do século XX, quando restrições à imigração começaram a se acentuar em diversos países, a livre circulação de pessoas ao redor do globo tomou um viés negativo. A força 
globalizante que liberou o capital ao final do século XX não se observou quanto ao fluxo de pessoas. Ao contrário, o que se observou foi o enrijecimento de leis migratórias nos países desenvolvidos, com aumento da repressão à imigração ilegal. Essa dupla face da globalização resultou em uma distorção nos sistemas fiscais nacionais. Frente a um capital com extrema mobilidade, e a uma força de trabalho muito menos móvel e atrelada ao território de um determinado país, os Estados nacionais passaram a competir pelo primeiro, oferecendo incentivos e reduzindo impostos que pudessem atrair o capital internacional; todavia, pressionados por déficits fiscais, a saída para compensar a perda arrecadatória foi construída por meio da maior tributação dos rendimentos do trabalho (AVI-YONAH, 2000).

Ao contrário dos trabalhadores, os investidores e as corporações multinacionais, valendo-se em parte da fragilidade de sistemas tributários nacionais não coordenados, bem como das limitações da soberania fiscal ao território dos respectivos Estados, puderam transferir seus lucros e rendimentos internacionalmente com maior liberdade, reduzindo significativamente as receitas de impostos (NABAIS, 2011). O que se observa, conforme Mota (2011, p. 170), é que as limitações políticas dos Estados impõem sérias restrições à tributação dos fatos geradores que podem ser mais "facilmente deslocalizados", e, com isso, "a capacidade dos Estados de arrecadar impostos e a distribuição da carga fiscal são afetadas, ocasionando a migração da tributação de bases mais voláteis - como o capital - para bases menos voláteis - como o trabalho.” Essa dicotomia também se aplica intercapital, quando se comparam as grandes corporações transnacionais e os pequenos e médios empresários. Enquanto as primeiras conseguem escapar dos entraves burocráticos e das exações fiscais impostas em âmbito nacionais, os pequenos e médios empreendedores - que são os maiores geradores de postos de trabalho - passam a suportar uma carga tributária cada vez mais intensa. Dessa forma, segundo Beck (2000, p. 6), "é uma ironia do destino que os perdedores da globalização no futuro terão de pagar por tudo - do estado de bem-estar a uma democracia operativa - enquanto os vencedores apuram polpudos lucros e escapam de sua responsabilidade para com o futuro da democracia." ${ }^{3}$

De fato, uma visada sobre a estrutura fiscal de boa parte dos países desenvolvidos e em desenvolvimento não apresenta uma trajetória de redução da tributação quando comparada proporcionalmente em relação ao produto interno bruto (PIB). Conforme dados levantados pela Organização para Cooperação Econômica e Desenvolvimento (OECD, na sigla em inglês), observa-se que, no Brasil, por exemplo, a carga tributária, nos últimos anos, tem-se situado em torno de 33\% (ORGANISATION FOR ECONOMIC CO-OPERATION AND DEVELOPMENT, 2017a), o que é muito próximo à média dos países da OECD, como Portugal (ORGANISATION FOR ECONOMIC CO-OPERATION AND DEVELOPMENT, 2017b). ${ }^{4}$ Nota-se, também, uma participação elevada dos impostos e dos tributos sobre o consumo e a produção, em comparação com os incidentes sobre lucros, rendas e capital, o que espelha uma tendência à regressividade do sistema fiscal brasileiro (ORGANISATION FOR ECONOMIC CO-OPERATION AND DEVELOPMENT, 2017a). 
Este cenário das estruturas fiscais não é acidental. Dada a facilidade com que as corporações multinacionais podem realocar geograficamente seus sistemas de produção, os países hospedeiros tendem a reduzir a tributação desses empreendimentos, como já anotamos. Porém, além disso, essas corporações tendem a escapar também da tributação de seus países de origem, que não querem ver suas companhias em desvantagem competitiva. Por outro lado, a imposição fiscal sobre os rendimentos do trabalho e empreendimentos locais de menor porte tem suas limitações econômicas e políticas. Como resultado, os países tendem a aumentar sua dependência por tributos regressivos, como os incidentes sobre a produção e circulação de produtos, mercadorias e serviços, e os tributos sobre a folha de pagamento (AVI-YONAH, 2000).

É importante destacar que esse movimento corporativo para evitar o pagamento de tributos não é necessariamente um crime no sentido típico atribuído ao termo, mas inexoravelmente é danoso para o financiamento dos estados. Evertsson (2016, p. 203), no contexto de estudo sobre a transformação da sociedade empresária Ikea para uma fundação e sua realocação da Suécia para os Países Baixos/Liechtenstein, enquadra as práticas corporativas de evitar a tributação - e as políticas estatais que as tornam possíveis - no rótulo de "crimes da globalização", os quais seriam "especificamente um produto das forças da globalização, e, por sua própria natureza, ocorrem em um contexto global”. Crime, nessa acepção, não seria propriamente um ilícito penal, mas dano social que "emerge de contínuas e sistemáticas relações de poder", e não necessariamente de típicos atos previstos em leis criminais. Esses atos danosos se desenvolvem sob um manto de promoção de menor intervenção estatal na economia, mas, ao contrário, a competição fiscal internacional e a concessão de incentivos fiscais a empresas multinacionais nada mais é do que uma política estatal que afeta a concorrência e o livre mercado. 5

Aponta-se, por outro lado, que a competição fiscal internacional não é necessariamente ruim, já que possibilita a Estados menos desenvolvidos atrair investimentos estrangeiros, compensando certas desvantagens em seu ambiente econômico com uma menor carga tributária, e, com isso, aumentando o nível de emprego de sua população (MACHADO; COSTA, 2016). ${ }^{6}$ Outro argumento que se coloca a favor da competição fiscal é que esta torna os governos mais eficientes e responsivos às preferências de sua população (FAULHABER, 2017). Essa competição pode ser benéfica se a perda arrecadatória se traduz em maior bem-estar para a população por meio da via do emprego e da geração de renda individual própria, compensando-se a potencial redução de financiamento do Estado social. No entanto, essa concorrência internacional se torna prejudicial (harmful tax competition) quando, ao afetar a localização de uma atividade, ${ }^{7}$ erode as bases fiscais de outros países, distorcendo os padrões de comércio e investimento internacionais, além de encorajar o não cumprimento das obrigações fiscais em outros países (KERZNER; CHODIKOFF, 2016).

Assim, a competição fiscal internacional é prejudicial especialmente quando, além de vantagens quanto à tributação propriamente dita, são oferecidos regimes especiais (notadamente 
quanto ao sigilo financeiro e fiscal), e, como os Estados desenvolvidos precisam reduzir seus tributos para concorrer com os menos desenvolvidos, "o resultado é uma diminuição global das receitas fiscais maior do que o aumento que resulta para os Estados menos desenvolvidos." (MACHADO; COSTA, 2016, p. 188). ${ }^{8}$ Nesse caso, pode-se afirmar que a competição fiscal internacional corrói as bases da autodeterminação fiscal dos países, ${ }^{9}$ e, além de aumentar as já gritantes diferenças entre detentores de capital e demais pessoas, tende a distanciar ainda mais os países ricos dos pobres (DIETSCH, 2015).

A tributação guarda uma relação de congruência e proporcionalidade com o papel que o Estado assume em cada nação. Quanto mais extensas forem as funções do Estado, maiores serão as necessidades de recursos e, consequentemente, mais intensa deverá ser a tributação. Contudo, mesmo as funções mais básicas de um Estado que se declare como mínimo demandarão recursos, pois, ainda que se assegurem somente direitos ditos "negativos", esses direitos terão custos que deverão ser suportados por tributos. ${ }^{10} \mathrm{O}$ fato, contudo, é que o papel do Estado nas democracias ocidentais tem sido ampliado nas últimas décadas, recebendo atribuições que vão muito além do estado "guarda-noturno". As constituições promulgadas a partir da segunda metade do século XX consagram, em diferentes graus, direitos à educação, ao trabalho, à moradia, além de deveres de proteção à cultura e ao meio ambiente. Mesmo nos Estados Unidos da América, onde a Constituição foi pouco alterada desde sua promulgação no século XVIII e se restringe à proteção de direitos de liberdade, propriedade e igualdade em sentido formal, pode-se afirmar que existe um Estado de bem-estar social criado pela via legislativa (HENKIN, 1978).

Tributação é uma política pública cujo foco reside em definir sobre quem - e em que medida - irão recair os encargos para a manutenção da atividade estatal. Significa, portanto, efetuar uma escolha redistributiva entre os que, na sociedade, serão mais onerados e os que, por outro lado, receberão benefícios fiscais. Nessa medida, as decisões sobre as políticas tributárias serão tomadas por seus elaboradores na medida de suas "crenças sobre os direitos de propriedade privada e o papel do Estado na sociedade civil", devendo tomar por base princípios de equidade e justiça, como a capacidade contributiva, o princípio do benefício e a equidade intergeracional (THOM, 2017, p. 33).

Em países como Brasil e Portugal, que contêm normas tributárias específicas em suas constituições, a política tributária continua sendo um espaço de discricionariedade política do legislador, mas trata-se de uma discricionariedade limitada tanto na sua forma quanto aos fins que deve perseguir. A política tributária, portanto, submete-se ao direito fiscal e à sua "permanente tensão entre os princípios da segurança jurídica e da justiça fiscal" (DOURADO, 2016, p. 236), devendo conformar-se ao modelo de Estado previsto na Constituição.

Essa busca por justiça fiscal deve moldar a política tributária de modo a permitir que todos tenham suas rendas identificadas e submetidas aos impostos na medida de suas capacidades econômicas. Nesse sentido, a política tributária precisa fornecer os meios para que se desenvolva uma eficaz administração dos impostos e dos demais tributos, evitando a evasão e a fraude fiscal, bem como o abuso de formas. 


\section{ELISÃO, EVASÃO E PLANEJAMENTO FISCAL ABUSIVO NO PLANO IN- TERNACIONAL}

Segundo Dourado (2016, p. 237-238), a não submissão de um determinado fato, ato ou negócio jurídico à incidência tributária, ou a redução de seu impacto tributário, pode resultar de uma série de fatores que estariam, assim, escalonados:

a) o fato ou ato jurídico não representa consumo, renda ou propriedade;

b) a forma jurídica escolhida para os atos ou negócio jurídicos tem a finalidade de eliminar ou reduzir a matéria tributável, mas essa finalidade não é a principal nem é artificial, havendo razões econômicas para sua prática além da mera economia de imposto;

c) o aproveitamento de lacunas intencionais ou não intencionais na legislação doméstica ou na interação entre legislações de diferentes países;

d) a adoção de formas jurídicas com a exclusiva finalidade de evitar a incidência tributária, sem correspondência entre a forma jurídica adotada e a substância do negócio;

e) os atos ou negócios constituem infrações penais ou administrativas.

Para os fins deste trabalho, devemos centrar nossa atenção nos três últimos casos, especialmente quanto ao chamado planejamento fiscal agressivo e à evasão fiscal no contexto internacional.

A evasão fiscal internacional consiste na proposital não declaração de rendas auferidas no exterior que, de outro modo, seriam tributadas, caso devidamente reportadas à administração tributária, distinguindo-se do planejamento fiscal, que consiste na prática de evitar a tributação se utilizando das opções previstas na própria legislação tributária. Ao contrário da evasão, que é uma atividade ilícita, o planejamento fiscal é a princípio aceitável, não podendo se afirmar que exista um dever de pagar tributos além do que é devido segundo a lei (KERZNER; CHODIKOFF, 2016).

No plano internacional, a evasão fiscal apresenta uma dimensão específica quanto ao problema das contas offshore. A modernização dos meios de transferência eletrônica de valores facilitou enormemente a abertura de contas em países distintos dos do país de domicílio dos contribuintes, em muitos casos, em paraísos fiscais, ${ }^{11}$ que buscam atrair capitais por meio de imposições fiscais mínimas ou negativas e estruturas jurídicas de sigilo bancário e opacidade quanto à propriedade de ativos (DIETSCH, 2015). ${ }^{12}$ Estima-se que mais de $6 \%$ (aproximadamente 8,5 trilhões de dólares) de toda a riqueza global transite em contas offshore (GRINBERG, 2016).

A princípio, não há, em geral, ilegalidade na abertura de contas em outros países, nem na transferência de valores para essas contas. O problema, no entanto, reside no fato de muitas vezes essas contas offshore serem utilizadas para ocultar rendas e valores não declarados à administração tributária.

Esse é um problema que afeta os países desenvolvidos, mas atinge os países em desenvolvimento em uma escala muito maior. Estima-se que o percentual da riqueza mantido em contas 
offshore seja menor do que 2\% nos EUA e $8 \%$ na Europa, enquanto esses números sobem para 25\% na América Latina e 33\% no Oriente Médio e na África, cifras que se agravam pela menor capacidade de promover auditorias e investigações por parte desses países (GRINBERG, 2012). Como essas contas offshore em muitos casos têm sido instrumento para os chamados "fluxos financeiros ilícitos" - ou a transferência internacional de recursos em violação à lei - elas tendem a atingir de um modo desproporcional as economias e os orçamentos dos países mais pobres, privando-os do necessário capital econômico para o desenvolvimento e a proteção dos direitos humanos (POGGE; MEHTA, 2016).

A evasão fiscal decorrente do uso de contas offshore "opacas" à administração fiscal tem como consequência imediata a redução da base tributável e o enfraquecimento da capacidade de financiamento do Estado. Além disso, a evasão fiscal provocada por contas offshore não declaradas e não detectadas também levanta preocupações quanto ao tratamento isonômico dos contribuintes e ao próprio engajamento destes na comunidade política, especialmente em países com histórico de impunidade e favorecimento a elites. Dessa forma, além de prejudicar a população mais necessitada pela falta de financiamento para programas sociais, a política tributária que falha em combater a evasão fiscal de uma elite econômica conduz a um ambiente em que o não pagamento de tributos passa a ter baixa reprovação social, traduzindo-se em menor grau de confiança nos governos (GRINBERG, 2016).

Questão distinta da evasão fiscal é a do planejamento fiscal agressivo. O planejamento fiscal não é um ato ilícito administrativo ou criminal, e a princípio se caracteriza como um exercício da liberdade fundamental do contribuinte de não se sujeitar a uma tributação além do que exige o ordenamento jurídico. Não obstante, o planejamento fiscal pode levar a situações concretas de injustiça fiscal, ${ }^{13}$ fazendo surgir para o legislador, no plano doméstico, um dever de suprir eventuais lacunas ou estabelecer cláusulas antielisivas ou antiabuso. Essas cláusulas, de modo geral, permitem a aplicação da chamada interpretação econômica dos fatos (DOURADO, 2016), prevista em Portugal no art. 11 no 3 da Lei Geral Tributária, e, no Brasil, no art. 116, parágrafo único, do Código Tributário Nacional. ${ }^{14}$

No plano internacional, uma das formas de planejamento fiscal agressivo se consolida por meio da prática do treaty shopping, ou seja, o contribuinte busca adquirir os benefícios de um tratado que não lhe está disponível, considerando sua residência fiscal, interpondo uma sociedade empresária em um país signatário de um tratado fiscal vantajoso (BECKER; WURM, 1988). Embora haja áreas em que a situação acima descrita não seja propriamente um desvio (transações e estruturas estabelecidas de boa-fé, por exemplo), caracteriza-se como impróprio o uso de um tratado quando o beneficiário da entidade interposta no país do tratado (normalmente uma corporação multinacional) não tem residência no país em que a entidade é criada, e essa entidade interposta tem uma atividade econômica mínima naquele país, servindo primordialmente para que a entidade que lhe controla possa usufruir de benefícios fiscais que não the alcançariam se essa prática não fosse adotada, como a isenção de impostos retidos na fonte em pagamentos 
internacionais (AVI-YONAH; PANAYI, 2010).

A OECD associa o planejamento fiscal agressivo a práticas relacionadas a "deduções excessivas de juros, instrumentos e entidades híbridas, e subsidiárias sem substância que se beneficiam de baixas tributações efetivas." (ORGANISATION FOR ECONOMIC CO-OPERATION AND DEVELOPMENT, 2017d, p. 15). Como destaca Dourado (2016, p. 258), o planejamento fiscal agressivo tem sido associado ao risco de evasão e elisão fiscal associado à globalização e ao livre fluxo de capitais, aparecendo relacionado "com a existência de fatos tributários interestaduais que envolvem ordenamentos jurídicos de baixa tributação", sendo "usado na documentação da OCDE e da União Europeia [...] como um conceito vago e relacionado com um apelo a uma coordenação fiscal internacional." Dessa forma, o planejamento fiscal agressivo é um conceito guarda-chuva ou "conceito-chapéu", sendo "descrito, em geral, como o comportamento adotado pelas multinacionais para explorar as oportunidades existentes para reduzir a carga fiscal como resultado da globalização e da interação das regras fiscais dos diferentes ordenamentos jurídicos." (DOURADO, 2016, p. 258-259). ${ }^{15}$

Embora o planejamento fiscal agressivo não tenha a mesma conotação ilícita da evasão fiscal, seus efeitos não são necessariamente menores sobre as receitas tributárias dos países. Estima-se que a perda de receita com o imposto sobre os lucros das sociedades empresárias multinacionais seja em torno de $4 \%$ a $10 \%$ das receitas totais dessas corporações, o que indicaria uma cifra entre 100 e 240 bilhões de dólares anuais. Essa perda se torna possível graças a políticas tributárias indevidas, com sistemas tributários nacionais não transparentes, ineficientes e que não se comunicam entre si (ORGANISATION FOR ECONOMIC CO-OPERATION AND DEVELOPMENT, 2015a).

Podemos dizer, então, que uma política tributária que não aborde adequadamente a questão da globalização é injusta por discriminar os contribuintes, seja por permitir a utilização de planejamentos fiscais agressivos, seja por permitir (por ineficiência ou conivência) a fraude e a evasão fiscal. Essa injustiça tende a assumir um círculo vicioso, pois a carga tributária dos contribuintes que voluntariamente cumprem com suas obrigações tributárias tenderá a aumentar, assim como o sistema tributário é forçado a tomar um viés mais regressivo, dependente de impostos indiretos sobre o consumo e a produção. Consequentemente, o Estado perde seu poder de financiamento das prestações do estado social, fazendo com que a população mais necessitada sofra duplamente, tanto pela redução de prestações sociais quanto pelo aumento dos impostos sobre o consumo. Esse cenário, por sua vez, ameaça a democracia em pelo menos duas dimensões:

a) reduz a confiança da população nas instituições do Estado, reduzindo o comprometimento com o esforço coletivo para o seu financiamento e;

b) reduz as condições materiais mínimas dos indivíduos, necessárias para o desenvolvimento de um ambiente democrático estável e participativo. 


\section{OS INSTRUMENTOS DE GOVERNANÇA GLOBAL DA TRIBUTAÇÃO}

Os desafios impostos pela globalização - especialmente a evasão fiscal e o planejamento fiscal agressivo - demandam uma nova governança da tributação. Essa governança não pode mais residir em iniciativas isoladas no âmbito doméstico sem coordenação internacional, sob pena de ineficácia e, consequentemente, não efetivação dos direitos humanos e das prestações do Estado social, levando à perpetuação da desigualdade de distribuição de renda. Nesse cenário, o Direito Internacional Tributário, compreendido a partir de um novo paradigma de centralidade da dignidade humana, "deve colocar-se ao serviço da promoção da transparência democrática, do desenvolvimento econômico e social e da justa distribuição de rendimentos à escala global", além do que deve promover "a transparência e a neutralidade econômica da legislação fiscal” (MACHADO; COSTA, 2016, p. 154-156).

Por essas razões, o Direito Fiscal Internacional vem ganhando renovada importância no contexto da construção de um sistema internacional que proporcione maior equilíbrio e coordenação dos países na área fiscal, reduzindo o espaço para a competição nociva e a erosão das fontes de financiamento do Estado social. A cooperação fiscal internacional preocupava-se inicialmente com mecanismos para evitar a dupla-tributação internacional, e, com o tempo, a evasão fiscal e o planejamento fiscal agressivo foram sendo incorporados às agendas das negociações e tratados internacionais (RIXEN, 2008).

Um instrumento indispensável para combater a evasão fiscal é disponibilizar informações sobre ativos financeiros às autoridades fiscais. De um modo geral, o fisco pode ter acesso a informações bancárias dos contribuintes relativamente aos ativos mantidos em instituições financeiras localizadas em seu território, respeitados os parâmetros legais e constitucionais. Trata-se de uma medida que está ao alcance da soberania estatal, incluindo-se a possibilidade de definições de penalidades administrativas e criminais para as instituições financeiras que se recusarem a fornecer informações.

No caso de contas offshore, essa situação se complica, pois o Estado não pode impor sua soberania além dos limites de seu território. Além disso, a resolução da evasão ligada às contas offshore também reside na informação. Se a administração tributária dispuser de instrumentos que permitam a identificação dos contribuintes que possuem conta no exterior, seria possivel, sem maiores dificuldades, verificar se esses valores foram declarados corretamente ao fisco, e, assim, "garantir que o uso de contas ocultas por poucos não aumente o ônus tributário de muitos." (GRINBERG, 2016, p. 16).

De forma semelhante, o planejamento fiscal agressivo também floresce em um ambiente de opacidade fiscal. Essa opacidade pode ser tanto vertical - na qual autoridades tributárias não dispõem de mecanismos para avaliar oportunamente os esquemas fiscais adotados por contribuintes em sua jurisdição - quanto horizontal - em que as autoridades fiscais carecem de instrumentos de compartilhamento de informações sobre as iniciativas de planejamento fiscal. 
A falta de um sistema eficaz de troca de informações é a peça-chave dos regimes fiscais prejudiciais que distorcem as decisões de investimentos e comprometem as bases fiscais da comunidade internacional, portanto tratados internacionais que permitam expandir a transparência fiscal internacional são fundamentais para uma melhor governança internacional da tributação (GUPTA, 2013).

Nessa seção, abordamos dois instrumentos internacionais que têm apresentado significantes desenvolvimentos para a ampliação da transparência fiscal internacional: os tratados relacionados ao FATCA e ao Projeto BEPS.

\subsection{TRATADOS RELACIONADOS AO FOREIGN ACCOUNT TAX COMPLIANCE ACT (FATCA)}

No que tange ao estabelecimento de uma arquitetura institucional para garantir a compliance tributária internacional e, dessa forma, instituir um mecanismo de combate ao uso indevido de contas offshore, o grande catalisador de um sistema de troca automática de informações foi a edição da legislação norte-americana conhecida como FATCA (Foreign Account Tax Compliance Act), em 2010 (GRINBERG, 2016). ${ }^{16}$

O FATCA foi uma norma implementada para lidar com um problema recorrente do fisco norte-americano (IRS), ${ }^{17}$ no tocante à falta de mecanismos legais ágeis para obter informações de instituições financeiras situadas no exterior. Enquanto as instituições sediadas nos EUA eram obrigadas a informar saldos e rendimentos de clientes, tais regras não se aplicavam aos bancos com sede no exterior, permitindo que residentes fiscais nos EUA (US persons) pudessem manter valores não declarados em contas offshore, enquanto os bancos depositários sustentavam a recusa de fornecer informações sob o argumento de direitos de sigilo bancário nos países em que se situavam. $\mathrm{O}$ escândalo envolvendo o banco suíço UBS, em 2008, e o vazamento de informações de correntistas do banco LGT de Liechtenstein, no mesmo ano, somados a argumentos de que os EUA perdiam cerca de US\$ 100 bilhões por ano com evasão fiscal em contas offshore forneceram o combustível político para que o Congresso norte-americano aprovasse a legislação pertinente ao FATCA (BYRNES; MUNRO, 2016).

Em síntese, o FATCA requer que instituições financeiras estrangeiras reportem o valor ou saldo das contas de correntistas norte-americanos, bem como dividendos, juros ou outras rendas por esses recebidas. Caso essas instituições financeiras não forneçam as informações bancárias de seus clientes norte-americanos, o FATCA prevê uma espécie de penalidade, consubstanciada na imposição de um tipo de "imposto" ${ }^{18}$ retido sobre pagamentos feitos por fontes norte-americanas a essas instituições (GRINBERG, 2016). Ademais, o FATCA impõe também diversos deveres de due diligence às instituições financeiras, no tocante à abertura de novas contas bancárias e em relação a contas antigas que se enquadrem nos parâmetros daquela norma (GUPTA, 2013). 
Um problema identificado quanto à aplicação do FATCA é que esse regime obrigava as instituições financeiras situadas no exterior a fornecer informações sobre contribuintes diretamente ao governo dos EUA, podendo, com isso, incorrer em violação de sigilo segundo a lei dos países em que estavam sediadas. A resolução para esse problema foi possível por meio de tratativas internacionais, em que Alemanha, França, Itália, Espanha e o Reino Unido - as cinco maiores economias europeias - resolveram cooperar com os EUA, evoluindo-se rapidamente para um projeto piloto no estilo do FATCA no âmbito do G20 (GRINBERG, 2016). Aponta-se que o FATCA foi a força motriz para a adoção de um intercâmbio automático de informações pelo G20 e pela OECD (KERZNER; CHODIKOFF, 2016). Dessa forma, podemos afirmar que o FATCA, apesar de ter surgido como uma norma de direito interno dos EUA, ${ }^{19}$ projetou-se como modelo para celebração de tratados bilaterais e multilaterais de trocas automáticas de informações de interesse fiscal.

A partir do FATCA, foram elaborados modelos-padrão de tratados internacionais, normalmente bilaterais, nos quais os países signatários se comprometem a adotar regras para permitir o acesso a informações de contribuintes residentes em um Estado, mas que possuam contas bancárias ou investimentos financeiros no outro. De modo geral, essa troca de informações se daria por meio da autoridade tributária de cada país (Modelo 1), muito embora haja a possibilidade de celebração de tratados em que a instituição financeira estrangeira forneça as informações bancárias dos cidadãos norte-americanos (US persons) diretamente à autoridade fiscal norte-americana (GUPTA, 2013).

O Brasil celebrou com os EUA tratado para implementação do FATCA em setembro de 2014, tendo esse tratado sido oficialmente incorporado ao direito interno brasileiro em 24 de agosto de 2015, por meio do Decreto 8.506 de 2015. No caso brasileiro, foi adotado o "modelo 1 ", com as trocas de informações sendo efetuadas anualmente por intermédio das "autoridades competentes" - "no caso dos EUA, o Secretário do Tesouro ou seu representante; e, no caso do Brasil, o Ministro da Fazenda, o Secretário da Receita Federal ou seus representantes" (BRASIL, 2015a). Em Portugal, o tratado para implementação do FATCA foi ratificado pelo Decreto no 53 de 2016 (PORTUGAL, 2016a), também adotando o “modelo 1". 20

\subsection{O PROJETO SOBRE A EROSÃO DE BASES IMPONÍVEIS E TRASLADO DE LU. CROS (BEPS)}

Outro relevante desenvolvimento do Direito Fiscal Internacional foi a iniciativa desenvolvida no âmbito do G20/OECD denominada Projeto BEPS - sigla correspondente à Base Erosion and Profit Shifting Project ou Projeto sobre a Erosão de Bases Imponiveis e Traslado de Lucros. É recorrente a afirmativa de que este projeto "supõe um novo paradigma de fiscalidade internacional." (BENÍTEZ, 2017, p. 85).

O Projeto BEPS, em linhas gerais, procura coordenar ações fiscais internacionais para que os países se estruturem e tomem medidas relacionadas ao planeamento fiscal agressivo 
(aggressive tax planning). Dessa forma, o Projeto BEPS procura abordar o problema das estratégias de planejamento fiscal que, embora não sejam necessariamente ilegais, exploram lacunas e falhas nas normas tributárias dos países para trasladar lucros para países de baixa tributação (ou mesmo sem tributação), minando a integridade dos sistemas fiscais e obtendo assim indevidas vantagens competitivas (ORGANISATION FOR ECONOMIC CO-OPERATION AND DEVELOPMENT, 2017c). O consenso que se formou no âmbito do G20 é que a erosão das bases fiscais não era decorrente de normas isoladas, mas da deficiência das legislações domésticas em lidar com as transformações no ambiente global de negócios e, principalmente, da falta de coordenação e de instrumentos eficazes de trocas de informação entre as autoridades tributárias (ORGANISATION FOR ECONOMIC CO-OPERATION AND DEVELOPMENT, 2015a).

Para tanto, o Projeto BEPS procura estudar e apresentar soluções para:

a) as incoerências e as lacunas nas normas fiscais dos Estados;

b) a adequação das normas fiscais aos avanços tecnológicos;

c) a promoção de um realinhamento da atividade fiscal frente ao poder econômico e;

d) o estabelecimento de medidas formais e materiais para prevenir o abuso das normas fiscais no âmbito internacional (GONZÁLEZ-BARREDA, 2017).

$\mathrm{Na}$ estrutura do Projeto BEPS, são previstas 12 ações, que abaixo listamos (ORGANISATION FOR ECONOMIC CO-OPERATION AND DEVELOPMENT, 2017d, p. 34-37): ${ }^{21}$

Ação 1 - Enfrentar os desafios fiscais da economia digital.

Ação 2 - Neutralizar os efeitos de arranjos financeiros híbridos que permitem a dupla não tributação (Hybrid Mismatch Arrangements).

Ação 3 - Construir regras efetivas relacionadas às sociedades estrangeiras controladas (CFC ou Controlled Foreign Company).

Ação 4 - Limitar a erosão das bases imponíveis envolvendo dedução de juros e outras despesas financeiras.

Ação 5 - Combater de forma mais efetiva práticas fiscais nocivas, levando em consideração a transparência e a substância (no caso, se há atividade substancial em um regime fiscal preferencial).

Ação 6 - Prevenir a concessão de benefícios de tratados em condições inapropriadas (evitar o "treaty shopping" por meio de regras para prevenir abuso de tratado).

Ação 7 - Prevenir que se contorne artificialmente o status de "estabelecimento permanente" para fins de tributação.

Ações 8 a 10 - Alinhar as regras relativas a preços de transferência (transfer pricing) com a geração efetiva de valor.

Ação 11 - Monitorar e mensurar o impacto econômico do BEPS.

Ação 12 - Prover um framework para regras de comunicação mandatória de planejamento fiscal a serem adotadas pelos países.

Ação 13 - Prover orientações para a documentação de preços de transferência e relatórios "país-a-país".

Ação 14 - Tornar os mecanismos de resoluções de disputa mais efetivos. 
Ação 15 - Desenvolver um instrumento multilateral para implementar medidas do BEPS e alterar tratados fiscais bilaterais.

Dentre as ações do BEPS, chama-nos especialmente a atenção a Ação 12, que trata das regras de divulgação ou comunicação obrigatória de esquemas de planeamento fiscal agressivo, tendo em vista que nos parece ser esta ação a que mais possa suscitar reações quanto a possíveis violações de liberdades fundamentais.

De acordo com o Relatório Final da Ação 12 do BEPS (ORGANISATION FOR ECONOMIC CO-OPERATION AND DEVELOPMENT, 2015b), os governos precisam ter acesso oportuno a informações relevantes de modo a identificar e a responder adequadamente a riscos decorrentes de esquemas de planejamento fiscal, portanto identificam-se três produtos-chave dessa ação, quais sejam:

a) recomendações para o projeto modular de regras de comunicações obrigatórias;

b) foco nos esquemas fiscais internacionais e consideração de uma ampla definição de benefícios fiscais para capturar transações relevantes e;

c) desenho e execução de modelos reforçados de compartilhamento de informações sobre esquemas internacionais de planejamento fiscal.

Destaca a doutrina que a Ação 12 do BEPS é uma recomendação sem caráter obrigatório e sem standard mínimo, de modo que os Estados têm liberdade para avaliar a relação de custo-benefício na implementação da medida (RANZ, 2017).

O Brasil, embora ainda não seja membro da OECD, aderiu ao Projeto BEPS em 2013, e é um membro do Global Forum on Transparency and Exchange of Information for Tax Purposes desde 2009 (ORGANISATION FOR ECONOMIC CO-OPERATION AND DEVELOPMENT, 2015c). O governo brasileiro procurou inserir em seu ordenamento jurídico a implementação da Ação 12 do BEPS por meio da Medida Provisória (MP) no 685 de 2015, que, em sua exposição de motivos, assim dispôs (BRASIL, 2015b, online):

4. A segunda medida proposta estabelece a necessidade de revelação de estratégias de planejamento tributário, que visa aumentar a segurança jurídica no ambiente de negócios do país e gerar economia de recursos públicos em litígios desnecessários e demorados. A ausência de informações completas e relevantes a respeito das estratégias de planejamentos tributários nocivos é um dos principais desafios enfrentados pelas administrações tributárias no mundo. $\mathrm{O}$ acesso tempestivo a tais informações oferece a oportunidade de responder rapidamente aos riscos de perda de arrecadação tributária por meio de fiscalização ou de mudança na legislação.

5. Nesta linha, o Plano de Ação sobre Erosão da Base Tributária e Transferência de Lucros (Plano de Ação BEPS, OCDE, 2013), projeto desenvolvido no âmbito da OCDE/G20 e que conta com a participação do Brasil, reconheceu, com base na experiência de diversos países (EUA, Reino Unido, Portugal, África do Sul, Canadá e Irlanda), os benefícios das regras de revelação obrigatória a administrações tributárias. Assim, no âmbito do BEPS, há recomendações relacionadas com a elaboração de tais regras quanto a operações, arranjos ou estruturas 
agressivos ou abusivos.

6. O principal objetivo dessa medida é instruir a administração tributária com informação tempestiva a respeito de planejamento tributário, além de conferir segurança jurídica à empresa que revela a operação, inclusive com cobrança apenas do tributo devido e de juros de mora caso a operação não seja reconhecida, para fins tributários, pela RFB. Ademais, destaca-se que a medida estimula postura mais cautelosa por parte dos jurisdicionados antes de fazer uso de planejamentos tributários agressivos.

Não obstante, a MP 685 encontrou fortes críticas. Na Câmara dos Deputados, a medida foi rejeitada e, apesar de ter sido reintroduzida pelo Senado Federal, foi novamente excluída pela Câmara no projeto que se converteu na Lei no 13.202 de 2015.

Portugal, por outro lado, que é membro da OECD e da União Europeia, tem em sua legislação nacional norma jurídica compatível com a Ação 12 do BEPS, tendo sido um "dos primeiros ordenamentos a introduzir o conceito de planejamento fiscal agressivo" (DOURADO, 2016, p. 259), consubstanciado no Decreto-Lei no 29 de 2008. Assim, essa norma - que obviamente antecede ao Projeto BEPS, mas que com este se alinha - consagrou, em relação ao planejamento fiscal, um regime que se fundamenta "na consagração de deveres de informação à administração fiscal tendo em conta que o funcionamento regular, eficaz, íntegro e justo do sistema fiscal também depende fortemente da informação que lhe seja reportada, em tempo oportuno." (PORTUGAL, 2008, online).

Os tratados relativos ao FATCA e ao Projeto BEPS - e, em nosso foco de abordagem, especialmente a Ação 12 do BEPS - trouxeram contribuição significativa para o problema de falta de transparência fiscal no âmbito internacional, tanto no plano vertical quanto no plano horizontal, bem como colocaram a coordenação e a cooperação internacional em matéria tributária em um novo patamar. A questão que nos é posta é se a adoção desses tratados e a sua colocação em prática pelas autoridades tributárias podem violar direitos humanos dos contribuintes.

\section{OS TRATADOS DE COOPERAÇÃO INTERNACIONAL PODEM VIOLAR DIREITOS HUMANOS?}

Os direitos humanos e a tributação mantêm entre si uma relação ambivalente. Se, por um lado, a tributação permite que o Estado efetive os direitos sociais previstos em lei ou na Constituição, por outro lado, podemos vislumbrar que exigências tributárias desproporcionais podem afetar a esfera de liberdade ou de privacidade dos indivíduos, e, neste caso, o direito tributário pode conformar uma esfera de proteção jurídica dos direitos humanos.

De forma análoga, conforme Kofler e Pistone (2011, p. 11), a tributação internacional e o direito tributário internacional podem ser um instrumento para tornar efetivos os valores sociais e jurídicos de uma nação, "incluindo um certo standard de direitos humanos além de suas fronteiras", bem como podem fornecer uma garantia no plano internacional para lidar 
com questões em que os ordenamentos jurídicos domésticos são falhos. No entanto, tratados internacionais de direito fiscal também podem colidir com direitos constitucionalmente garantidos, entre os quais identificamos os direitos de privacidade e de liberdade de iniciativa.

Essa questão é especialmente relevante quando situamos os tratados internacionais de direito tributário no contexto da hierarquia das fontes de direito. Em Portugal, a doutrina aponta a primazia do direito convencional sobre os atos legislativos, mas enfatiza a subordinação dos tratados sobre dupla tributação à Constituição (MACHADO; COSTA, 2016). No Brasil, onde o art. 98 do Código Tributário Nacional expressamente prevê que "tratados e as convenções internacionais revogam ou modificam a legislação tributária interna, e serão observados pela que lhes sobrevenha" (BRASIL, 1966, online), podemos afirmar que os tratados internacionais de direito tributário possuem uma eficácia supralegal, colocando-se acima da legislação infraconstitucional, mas os atos deles decorrentes submetem-se ao controle de constitucionalidade. ${ }^{22}$

Vejamos o caso do sigilo bancário. Uma tese possível é que o sigilo bancário estaria compreendido entre os direitos de privacidade, reconhecidos como direitos fundamentais tanto em Portugal, conforme art. 26.1 da Constituição da República Portuguesa (CRP), quanto no Brasil (art. 5, incisos X e XII, da Constituição de 1988/CRFB), portanto a obrigação de bancos fornecerem diretamente ao fisco informações sobre seus correntistas seria uma violação de direitos humanos.

A defesa de um direito de sigilo bancário frente ao fisco colide com as práticas e as políticas tributárias da maioria dos países desenvolvidos, onde esta tese, segundo Grinberg (2016), perdeu tanto a batalha moral quanto a jurídica. No caso do sigilo bancário transfronteiriço, faz-se certa defesa baseada no argumento de que esse sigilo protegeria os cidadãos de governos autoritários ou corruptos. No entanto, deve-se levar em consideração que um sistema internacional de trocas de informações fiscais deve ser limitado a esse propósito, considerando que de fato existem governos ilegítimos, os estados poderiam avaliar se deveriam ou não fornecer informações bancárias. Esta ponderação entre o risco político para o cidadão do país requisitante e o direito desse país em identificar as rendas e os bens dos contribuintes sujeitos à sua jurisdição é um dos grandes desafios para o direito tributário internacional nas próximas décadas. (GRINBERG, 2016). ${ }^{23}$

Em Portugal, de acordo com Santos e Palma (2013), o sigilo bancário não é um direito absoluto, podendo sofrer restrições. Desde 2006, a Autoridade Tributária e Aduaneira (AT) tem poder de acessar informações bancárias, dispensando-se o consentimento do detentor dessas informações protegidas, nos casos em que há indícios de crimes fiscais; indícios de não veracidade ou incompletude em informações que deveriam ser prestadas de acordo com a lei; indícios de aumento patrimonial não justificado; entre outros casos. Além disso, de acordo com o Decreto-lei 29 de 2008, foram estabelecidos deveres de comunicação à AT para combater planejamentos fiscais abusivos (SANTOS; PALMA, 2013).

No Brasil, o sigilo bancário não é considerado um direito absoluto. O Supremo Tribunal 
Federal, em diversas ocasiões, já havia afirmado a possibilidade de quebra desse sigilo por meio de ordem judicial. ${ }^{24}$ Com a Lei Complementar 105, de 2001, atribuiu-se competência à autoridade fiscal para requerer, diretamente às instituições financeiras, dados bancários de contribuintes. Embora esta lei tenha sido questionada perante o Supremo Tribunal Federal (Recurso Extraordinário 601.314), a Corte considerou-a constitucional, afirmando que a correta identificação de bens e direitos do contribuinte é fundamental para que se possa dar concretude aos princípios da igualdade fiscal e da capacidade contributiva. Assim, muito embora a Lei Complementar 105 tenha instituído uma restrição ao direito fundamental de privacidade do contribuinte, esta restrição não feriu o princípio da proporcionalidade considerado em suas dimensões de adequação, necessidade e proporcionalidade em sentido estrito - já que foram estabelecidos critérios objetivos para a requisição das informações pelo fisco e que não foi violado o núcleo essencial do direito de privacidade, pois as informações que antes estavam protegidas por sigilo bancário passaram a estar protegidas por sigilo fiscal. Desse modo, o Tribunal ressaltou que: ${ }^{25}$

De fato, o acesso expedito e direto às informações bancárias dos contribuintes revela-se absolutamente indispensável para que a Autoridade Fazendária possa levar a cabo seu mister institucional de fiscalizar e cobrar tributos no cenário econômico atual.

A rigor, não parece haver meios capazes de assegurar à Autoridade Fazendária o mesmo resultado pretendido sem implicar ainda maior restrição aos direitos fundamentais dos contribuintes.

[...]

Por outro lado, não se diga que a Administração poderia, sempre que preciso, adotar procedimentos judiciais para que o Poder Judiciário lhe franqueasse o acesso às informações necessárias à fiscalização tributária.

Pelo que já se viu neste julgamento, parece estar claro que esse proceder seria inviável, na prática. Não atenderia às necessidades da Administração Tributária, seja em termos de celeridade, ou de troca de informação, na forma do previsto em acordos internacionais celebrados (BRASIL, 2016, online).

O caso subjacente ao Recurso Extraordinário 601.314 não era diretamente relacionado à observância de tratados internacionais tributários, mas é digno de nota que as recentes transformações na governança internacional da tributação foram levadas em consideração nos argumentos da Corte, como fica explícito no trecho abaixo transcrito, em que, expressamente, faz-se referência ao acordo do FATCA celebrado entre Brasil e EUA:

Aliás, as informações trazidas a este julgamento deixam claro que há uma verdadeira tendência mundial, hoje em curso, no sentido de ampliar, cada vez mais, a troca de informações fiscais entre países e reduzir o espaço, nas legislações nacionais, para sigilo bancário contra o Fisco.

Num contexto de erosão de bases tributárias e crescente volatilidade de capitais, essas certamente representam medidas importantes para garantir efetividade à fiscalização tributária e combater a evasão, o planejamento tributário 
internacional abusivo, a lavagem de dinheiro e mesmo a corrupção.

$[\ldots]$

Evidentemente, aqui não se pretende ler a letra da Constituição com base nos acordos internacionais. A supremacia da Constituição impõe antes o contrário: submeter os tratados e convenções internacionais ao parâmetro constitucional.

O fato é que perceber o contexto econômico em que se insere o tema em deslinde é essencial para compreender o sentido e a importância das disposições impugnadas e também as consequências deste julgamento, inclusive no plano internacional.

Ainda a esse respeito, não posso deixar de mencionar, à guisa de ilustração, o Decreto n. 8.506, de 24 de agosto de 2015, que promulga o Acordo entre o Governo da República Federativa do Brasil e o Governo dos Estados Unidos da América para Melhoria da Observância Tributária Internacional e Implementação do FATCA, firmado em Brasília, em 23 de setembro de 2014.

O Acordo trata justamente do Intercâmbio de Informações relativas a Tributos e prevê que se envidem esforços mútuos no sentido de assegurar que a troca de informação para fins tributários se dê de maneira automática, de acordo com os termos e procedimentos definidos pelas autoridades competentes dos dois países (BRASIL, 2016, online).

Os argumentos lançados pelo Supremo Tribunal Federal no Recurso Extraordinário 601.314 parecem indicar que a Corte adotaria entendimento semelhante caso fosse questionada a constitucionalidade do Decreto 8.506 de 2014, mas é preciso destacar que o acordo do FATCA não é materialmente idêntico à Lei Complementar 105. Enquanto esta lei trata de procedimentos específicos para determinados contribuintes, a troca de informações pelo acordo do FATCA é muito mais genérica, e os dados obtidos pelo fisco nacional seriam compartilhados com a autoridade fiscal dos EUA.

Esta peculiaridade dos acordos do FATCA foi o ponto ressaltado no Parecer no 22/2016 da Comissão Nacional de Proteção de Dados (CNDP) de Portugal, sobre o anteprojeto de Decreto-lei para a regulação complementar de implementação do FATCA naquele país. A CNDP considerou, no caso daquele anteprojeto, ser "claramente excessivo conhecer informação financeira em tão elevada escala de titulares de dados pessoais [...] sem que sejam definidos critérios mínimos (e proporcionais) que indiquem comportamentos fiscais ilícitos, ou que ao menos indiquem situações de risco de tais comportamentos" (PORTUGAL, 2016b, online), sendo o anteprojeto inconstitucional por impor uma restrição desproporcional ao direito de privacidade previsto na CRP (PORTUGAL, 2016b). ${ }^{26}$

De fato, os tratados do FATCA e os outros tratados similares de troca automática de informações bancárias, bem como as normas domésticas que os instrumentalizam apresentam um elevado grau de generalidade no acesso às informações bancárias dos contribuintes, no qual não há critérios de acesso relativos a comportamentos ou indícios de práticas de evasão fiscal ou criminosas. Não obstante, não nos parece que haja uma inconstitucionalidade prima facie nessas normas.

Em primeiro lugar, entendemos que estas normas atendem aos requisitos de adequação 
e necessidade do princípio da proporcionalidade, pois são instrumentos hábeis para que as administrações tributárias tenham acesso a informações sobre transações e movimentações financeiras indispensáveis a uma eficiente e justa auditoria fiscal em tempos de finanças globalizadas, não se vislumbrando outras medidas que pudessem atender a esses fins com menor impacto sobre os direitos constitucionais dos contribuintes.

Quanto à proporcionalidade em sentido estrito, é inegável que essas normas impõem uma restrição aos direitos de privacidade e proteção de dados dos contribuintes. Todavia, tais direitos precisam ser sopesados com a garantia de todos os demais direitos que só podem se concretizar com os recursos advindos da tributação. Como destacado pelo Supremo Tribunal Federal no Recurso Extraordinário 601.314, é dever do Estado buscar uma justa tributação e um tratamento igualitário dos contribuintes, o que somente poder-se-á realizar com a identificação da renda e da correta mensuração da capacidade contributiva dos cidadãos e das demais pessoas sujeitas à sua jurisdição fiscal. Ademais, as administrações tributárias só teriam acesso a saldos das contas no exterior mantidas por contribuintes com residência fiscal em sua jurisdição, e não a informações detalhadas que pudessem vulnerar por completo o núcleo essencial do direito à privacidade. ${ }^{27}$

A implementação da Ação 12 do Projeto BEPS também nos remete a considerações sobre possíveis colisões com direitos constitucionais. No caso do direito à privacidade (que nos parece ter uma aplicação neste aspecto mais restrita às pessoas físicas), entendemos ser aplicáveis os mesmos argumentos que já expusemos quanto aos tratados do FATCA. A Ação 12 do BEPS, por outro lado, também levanta questões ao direito à livre iniciativa e às liberdades econômicas em geral, previstas no art. 170 da CRFB e no art. 61 da CRP.

No Brasil, problemas jurídico-constitucionais pertinentes à Ação 12 do BEPS permanecem no plano puramente abstrato, já que foi frustrada sua implementação legal no plano doméstico, e o art. 116, parágrafo único, do Código Tributário Nacional, quando muito permitiria que o fisco utilizasse a interpretação econômica dos fatos para exigir tributos, em nada se aproximando da imposição de dever aos contribuintes de revelar estratégias de planejamento fiscal.

$\mathrm{Na}$ França, norma que implementou a Ação 12 do BEPS (Loi relative à la transparence, à la lutte contre la corruption et à la modernisation de la vie économique) foi questionada com sucesso perante a Corte Constitucional daquele país. A referida lei - que impunha às companhias com volume de negócios superior a 750 milhões de Euros divulgar um relatório público país-a-país anualmente - foi questionada judicialmente por um grupo de deputados e senadores que entendiam haver violação do direito constitucional à liberdade de empresa, tendo em vista que em tal relatório haveria informações essenciais pertinentes à estratégia comercial daquelas entidades. Embora a Corte tenha concordado com o argumento do governo francês, no sentido de que a norma atacada atendia ao fim constitucional de lutar contra a evasão tributária e a fraude fiscal, a decisão do Tribunal acatou o pedido dos autores quanto ao dever de as companhias tornarem públicas suas estratégias fiscais, reconhecendo sua inconstitucionalidade 
(ANGHILERI, 2016; FRANÇA, 2016).

Por outro lado, conforme anota Dourado (2016, p. 260), “o Tribunal Europeu dos Direitos do Homem já decidiu que não existe um direito ao silêncio relacionado com o cumprimento de obrigações fiscais (caso Chambaz vs Switzerland).”

Nota-se, portanto, haver uma real controvérsia (não somente jurídica, mas também de política tributária) envolvendo os novos poderes atribuídos às autoridades fiscais domésticas em razão de tratados internacionais, como o FATCA e o Projeto BEPS. Essas controvérsias provavelmente serão enfrentadas por tribunais dos países que efetivamente adotarem essas medidas. Porém, não podemos perder de vista que uma das chaves para reduzir o abismo fiscal entre países desenvolvidos e em desenvolvimento e, por decorrência, a enorme disparidade em termos de respeito aos direitos humanos é a "transparência financeira internacional", implantando-se um sistema de troca automática de informações fiscais em nível internacional, e a "obrigação de empresas multinacionais reportarem vendas, salários e impostos pagos país a país em cada jurisdição em que operarem.” (POGGE; MEHTA, 2016, p. 6). Dessa forma, será preciso desenvolver caminhos para efetivar a transparência fiscal na governança internacional da tributação sem que os direitos de privacidade e livre inciativa tenham seus núcleos essenciais vulnerados.

A análise efetuada nesta seção indica que não há, a princípio, uma violação de direitos humanos na adoção de medidas tendentes a efetivar tratados voltados a incrementar a transparência fiscal internacional, mas é preciso ter cautela na implementação dessas medidas pelas autoridades tributárias de cada país. Para que os dados pessoais e estratégias fiscais e concorrenciais de pessoas físicas e jurídicas sejam preservados, exigir-se-á um grande esforço para o gerenciamento seguro por parte das autoridades tributárias. Em tempos de complexa segurança da informação digital, este com certeza será um grande desafio, pois vazamentos de dados sigilosos de contribuintes podem caracterizar-se como violação concreta de direitos humanos e fornecer o combustível necessário para reverter os avanços observados nos últimos anos na governança fiscal internacional.

\section{CONSIDERAÇÕES FINAIS}

Os desafios para a construção de sistemas tributários eficientes e justos adquirem novas dimensões na sociedade contemporânea. Além dos tradicionais problemas enfrentados por governos e legisladores ao moldarem a estrutura fiscal do Estado, a globalização e a decorrente mobilidade do capital internacional adicionam novas complexidades que extrapolam a capacidade das entidades estatais de controlar situações que escapam ao paradigma westfaliano. Facilitadas pela falta de transparência e de cooperação internacional, bem como pela competição fiscal entre os Estados, a evasão tributária e o planejamento fiscal abusivo ameaçam a capacidade dos Estados de financiarem as prestações do Estado social e efetivarem os direitos humanos, o que, além de comprometer os orçamentos públicos, abala a confiança nos governos e a sua legitimidade democrática para obter mais recursos da sociedade. Esses 
efeitos deletérios têm atingido tanto os países considerados desenvolvidos quanto os países em desenvolvimento, muito embora o impacto nestes últimos seja mais intenso.

Surge, portanto, a necessidade de construir-se uma governança global da tributação, por meio da coordenação internacional dos esforços fiscais. Neste cenário, o Direito Tributário Internacional assume novos contornos. Os tratados tributários internacionais, além de abordar questões ligadas à dupla tributação, passam a ter foco nos problemas relacionados à evasão fiscal e ao planejamento tributário agressivo, buscando suprimir a competição fiscal nociva e as práticas de treaty shopping, assim como estabelecer sistemas bilaterais e multilaterais de cooperação e troca de informações fiscais.

Neste trabalho, abordamos especificamente dois instrumentos deste paradigma de governança global da tributação - os acordos relativos ao FATCA e à Ação 12 do Projeto BEPS da OECD - que projetam uma nova era em termos de cooperação e transparência fiscal internacional. Pudemos analisar, também, possíveis questionamentos quanto à violação de direitos de privacidade e de livre iniciativa das normas que, nos planos nacionais, procuram implementar tais instrumentos internacionais.

O estudo de casos extraídos de decisões do Supremo Tribunal Federal e do direito comparado indicam que a implementação de tratados internacionais para cooperação e transparência fiscal, embora controvertida, não é prima facie inconstitucional. Os direitos de privacidade e livre inciativa precisam ser compatibilizados com a busca da igualdade e da justiça fiscal, que dependem intrinsecamente da precisa identificação e mensuração da capacidade contributiva das pessoas físicas e jurídicas, não se sustentando a hipótese de um direito fundamental à ocultação do patrimônio. Não obstante, o uso desses novos instrumentos impõe maiores responsabilidades às autoridades tributárias, que deverão tomar medidas necessárias à preservação do sigilo das informações bancárias e fiscais dos contribuintes, especialmente nesta era de complexa segurança digital em que vivemos, sob pena de configurar-se, em concreto, uma violação inconstitucional dos direitos de privacidade e livre iniciativa.

\title{
GLOBAL GOVERNANCE OF TAXATION AND THE INTERNATIONAL TREATIES FOR TAX TRANSPARENCY AND COOPERATION
}

\begin{abstract}
This paper aims to analyze the new instruments of global governance of taxation and the controversy over the possible unconstitutionality of the domestic rules that implement international tax treaties of cooperation and automatic exchange of information. The paper addresses the impacts of globalization on tax systems, pointing out that the mobility of international capital and the absence of efficient and transparent mechanisms for cooperation and exchange of tax information facilitate tax evasion and aggressive tax planning. The isolated and uncoordinated domestic tax systems are not capable of responding adequately to these
\end{abstract}


undesirable effects, and, therefore, States lose their ability to finance the realization of human rights. In this scenario, a new paradigm of global governance of taxation and International Tax Law emerges, turning its attention to the problems of tax evasion and the erosion of tax bases. Following these premises, this article presents two instruments of global governance of taxation - the FATCA treaties and the Action 12 of the BEPS Project. Finally, we investigate the possible violation of privacy and freedom of enterprise rights due to the implementation of these international instruments in the national legal order, developing an analysis based on precedents of the Federal Supreme Court and comparative law. The paper concludes that the implementation of international treaties for cooperation and fiscal transparency is not prima facie unconstitutional, although it generates greater responsibilities for the tax authorities regarding the preservation of taxpayers' rights.

Keywords: International Tax Law. Constitutional Law. International Tax Cooperation. Privacy. Freedom of Enterprise.

\section{GOBERNANZA GLOBAL DE LA TRIBUTACIÓN Y LOS TRATADOS INTERNACIONALES DE COOPERACIÓN Y TRANSPARENCIA FISCAL}

\section{RESUMEN}

Este trabajo tiene como objetivo analizar los nuevos instrumentos de gobernanza global de la tributación y la controversia sobre la posible inconstitucionalidad de las normas domésticas que implementan tratados fiscales internacionales de cooperación e intercambio automático de informaciones. El trabajo aborda los impactos de la globalización sobre los sistemas tributarios, apuntando que la movilidad del capital internacional y la ausencia de mecanismos eficientes y transparentes de cooperación e intercambio de informaciones fiscales facilitan la evasión fiscal y la planificación tributaria agresiva. Sistemas fiscales domésticos aislados y no coordinados no son capaces de presentar una respuesta adecuada a estos efectos no deseados y, en consecuencia, los Estados pierden su capacidad para financiar la efectividad de los derechos humanos. En este escenario, surge un nuevo paradigma de gobernanza global de la tributación y del Derecho Fiscal Internacional, que pone su atención en los problemas de la evasión fiscal y de la erosión de las bases imponibles. A partir de estas premisas, este artículo presenta dos instrumentos de gobernanza global de la tributación - los tratados relativos al FATCA y la Acción 12 del Proyecto BEPS. Por último, se investiga la posible violación de derechos de privacidad y de libre iniciativa en razón de la aplicación de estos instrumentos internacionales en el ordenamiento jurídico nacional, efectuándose un análisis a partir de precedentes del Supremo Tribunal Federal y del derecho comparado. Se concluye que la implementación de tratados internacionales para cooperación y transparencia fiscal no es prima facie inconstitucional, aunque genera mayores responsabilidades a las autoridades tributarias 
en lo que se refiere a la preservación de los derechos de los contribuyentes.

\author{
Palabras clave: Derecho Fiscal Internacional. Derecho constitucional. Cooperación Fiscal \\ Internacional. Privacidad. Libertad de Iniciativa.
}

1 Deve-se levar em consideração que a expressão Direito Fiscal Internacional pode levar à falsa impressão de que o contribuinte que toma parte em fatos geradores que ocorrem ou se relacionam a dois ou mais países estará sujeito a um corpo único de normas jurídicas que definirão sua obrigação tributária, quando de fato esse contribuinte que realiza operações transfronteiriças estará sujeito e deverá cumprir as normas internas de cada país quanto à repercussão fiscal desses fatos (KERZNER; CHODIKOFF, 2016, p. 32). O Direito Fiscal Internacional, na verdade, cria regras para que esses países possam cooperar entre si, tanto para evitar a dupla tributação quanto para evitar que contribuintes maliciosamente tentem escapar de qualquer tributação, com medidas para evitar o planejamento fiscal agressivo e a fraude fiscal por meio de contas offshore.

2 Em linhas gerais, a competição fiscal danosa (harmful tax competition ou "race to the bottom"), embora não tenha uma definição precisa, costuma referir-se "aos esforços empreendidos por determinados países para alterar o imposto sobre renda de pessoas jurídicas para atrair investidores, rendas ou outros recursos de outros países. Esses esforços podem variar desde a disponibilização de uma baixa tributação da renda das empresas ao tratamento mais favorecido de alguns contribuintes." (FAULHABER, 2017, online).

3 Nota-se que a competição fiscal internacional decorrente da globalização levou a uma redução média da tributação das pessoas jurídicas no âmbito da OECD de 50\% (em 1988) para 32\% (em 2008); os Estados Unidos, com uma alíquota de 35\%, apresentava o patamar mais alto na OECD (AUERBACH; SMETTERS, 2017, p. 1). Com a nova Lei Tributária aprovada recentemente pelo Congresso Norte-americano, sancionada pelo Presidente Donald Trump, esta alíquota caiu para 21\%, o que pode levar a uma nova rodada de reduções de tributos para corporações.

4 Nota-se, aliás, conforme Folloni e Yazbek (2013), um acentuado crescimento da carga tributária brasileira a partir da década de 1990.

5 Conforme Evertsson (2016, p. 214), "Isso sugere que, na economia de mercado, não há espaço para o auxílio estatal dado às empresas por meio, por exemplo, de incentivos fiscais. No entanto, a concorrência entre os estados para oferecer auxílio estatal às empresas criou mais elisão fiscal entre as corporações porque elas podem se tornar globais e selecionar os territórios que melhor se adaptem às suas necessidades fiscais."

6 De qualquer modo, a competição fiscal internacional sempre provocará uma "interdependência fiscal", ou seja, a política fiscal de um país causará externalidades econômicas em outros (DIETSCH, 2015, p. 36).

7 Nesse caso, ocorreria uma quebra da chamada neutralidade fiscal. A neutralidade fiscal pode ser definida como a situação em que considerações acerca da repercussão tributária não afetam ou pouco afetam as decisões sociais ou econômicas (MESSERE, 1993). Conforme Machado e Costa (2016, p. 156), a neutralidade econômica fiscal deve ser entendida de forma tríplice, como neutralidade de exportação de capitais, neutralidade de importação de capitais e neutralidade nacional.

8 "Enquanto a concorrência fiscal pode ter o mesmo efeito descendente sobre os impostos que a concorrência por clientes tem sobre os preços, a diminuição das receitas fiscais não conduz necessariamente a um aumento do bem-estar." (FAULHABER, 2017).

9 A autodeterminação fiscal de um país compreende tanto a capacidade de fixar as escolhas relativas ao tamanho de seu orçamento público quanto em relação à distribuição de encargos e benefícios na sociedade (DIETSCH, 2015, p. 35).

10 "A legal right exists, in reality, only when and if it has budgetary costs." (HOLMES; SUNSTEIN, 1999, p. 19).

11 'O termo 'paraíso fiscal' [tax haven] não é precisamente definido na literatura do direito fiscal e, geralmente, refere-se a países que são capazes de se financiar sem impostos sobre renda ou com impostos apenas nominais e, algumas vezes, são usados por não-residentes para escapar da tributação em seus países de residência; esse 
termo também pode ser definido de maneira ampla para descrever países que arrecadam receitas significantes de seu imposto de renda, mas seus sistemas tributários oferecem vantagens fiscais para atrair investimentos de outros países." (PANKIV, 2013, p. 156).

12 Conforme Vasconcellos (2012, p. 348), "Os paraísos fiscais são o grande alvo das empresas que desejam efetuar evasão fiscal, em virtude do sigilo bancário, gerando verdadeira economia paralela, fazendo com que a autoridade tributária deixe de arrecadar milhões."

13 "[W] hen taxpayers see multinational corporations legally avoiding income tax, it undermines voluntary compliance by all taxpayers." (ORGANISATION FOR ECONOMIC CO-OPERATION AND DEVELOPMENT, 2017c, online).

14 Observe-se que a chamada "interpretação econômica" em Direito Tributário não é uma novidade, que, segundo Jarach (2004, p. 400), remonta à Alemanha de 1919.

15 Vide, conforme Faulhaber (2017), que a distinção entre a elisão internacional (tax avoidance) e a competição fiscal (tax competition) não é precisa. A elisão seria um esforço dos contribuintes, enquanto a competição se daria entre países; no entanto, uma não existe sem a outra ou sem a colusão entre governos e corporações multinacionais. De forma correlata, medidas que procuram combater a elisão incidem sobre a competição fiscal e vice-versa.

16 Não se pode olvidar, contudo, que há críticas contundentes sobre o FATCA na literatura especializada em direito tributário nos EUA, entre essas críticas, estaria a imprecisão metodológica das premissas que levaram à sua instituição e à preocupação com custos e ineficiência do programa como um todo (vide BYRNES; MUNRO, 2016).

17 Sigla que representa Internal Revenue Service, ou equivalente norte-americano à Receita Federal brasileira.

18 Como Grinberg (2016, p. 17) alerta, o FATCA não é propriamente um imposto na fonte, mas um "regime punitivo com a intenção de forçar instituições financeiras estrangeiras a fornecer informações à IRS."

19 O FATCA foi introduzido no Internal Revenue Code de 1986 por meio do Hiring Incetives to Restore Employments (HIRE) Act de 2010 (BYRNES; MUNRO, 2016, p. 3).

20 Para uma lista atualizada dos países que celebraram tratados do FATCA, vide Estados Unidos da América (2017). Note-se que a maioria dos países celebraram com os EUA tratados no "modelo 1". Entre os que celebraram tratados no "modelo 2", destacam-se Chile, Japão, Suíça e Taiwan (ESTADOS UNIDOS DA AMÉRICA, 2017).

21 Para uma descrição mais detalhada das ações do Projeto BEPS, vide Machado e Costa (2016, p. 161-162).

22 Nesse sentido, vide Supremo Tribunal Federal, Ação Direta de Inconstitucionalidade 5240, Relator(a): Min. LUIZ FUX, Tribunal Pleno, julgado em 20/8/2015, pub. 1-2-2016.

23 Embora neste trabalho tenhamos assumido uma posição no sentido de haver um dever fundamental de pagar os tributos, exigidos de acordo com a Constituição, há, por outro lado, defesas consistentes em sentido contrário. Nessa linha, conferir McGee (2012).

24 Vide, como exemplo, Supremo Tribunal Federal. Mandado de Segurança 23452, Relator(a): Min. CELSO DE MELLO, Tribunal Pleno, julgado em 16/9/1999, DJ 12-05-2000 PP-00020.

25 Vide Supremo Tribunal Federal, Recurso Extraordinário 601314, Relator(a): Min. EDSON FACHIN, Tribunal Pleno, julgado em 24/2/2016, Acórdão Eletrônico Repercussão Geral - Mérito DJe-198 div. 15-9-2016 pub. 16-9-2016

26 Em suas razões, a CNDP cita o Acórdão do Tribunal de Justiça da União Europeia nos processos C-292/12 e C-594/12, no qual se conclui que, na "Diretiva 2006/24, o legislador da União excedeu os limites impostos pelo respeito do princípio da proporcionalidade à luz dos artigos $7 .^{\circ}, 8^{\circ}$ e $52 .^{\circ}, \mathrm{n} .^{\circ} 1$, da Carta", impondo uma desproporcional restrição aos direitos fundamentais à vida privada e à proteção dos dados pessoais, tendo em vista "que a Diretiva 2006/24 abrange de maneira geral todas as pessoas, todos os meios de comunicação eletrónica e todos os dados relativos ao tráfego, não sendo efetuada nenhuma diferenciação, limitação ou exceção em função do objetivo de luta contra as infrações graves", e, dessa forma, "abrange, em geral, todas as pessoas que utilizam serviços de comunicações eletrônicas, sem que, no entanto, as pessoas cujos dados são conservados se encontrem, ainda que indiretamente, numa situação suscetivel de dar lugar a ações penais. Assim, aplica-se 
mesmo a pessoas em relação às quais não haja indícios que levem a acreditar que o seu comportamento possa ter um nexo, ainda que indireto ou longínquo, com infrações graves." (UNIÃO EUROPEIA, 2014, online).

27 Kerzner e Chodikoff (2016, p. 278-280) relatam um interessante caso levado à Corte Federal no Canadá, questionando o acordo de troca de informações celebrado por aquele país com os EUA. O tribunal canadense, apesar de achar que o objeto do tratado potencialmente poderia ser um processo custoso e desnecessário, não o considerou inconstitucional.

\section{REFERENNCIAS}

ANGHILERI, Davide. France: public county-by-country reporting declared unconstitutional. 2016. Disponivel em: <https://mnetax.com/france-public-county-country-reporting-declared-unconstitutional-18524>. Acesso em: 15 jan. 2018.

AUERBACH, Alan J.; SMETTERS, Kent. Tax reform in a changing economy. In: UERBACH, Alan J.; SMETTERS, Kent (Org.). The economics of tax policy. New York City: Oxford University Press, 2017. p. 1-12.

AVI-YONAH, Reuven. Globalization, Tax Competition and the Fiscal Crisis of the Welfare State. Harvard Law Review, v. 113, n. 7, p. 1573-1676, 2000.

AVI-YONAH, Reuven; PANAYI, C. H. Rethinking treaty shopping: lessons for the European Union. In: LANG, Michael; PISTONE, Pasquale (Org.). Tax treaties: building bridges between law and economics. Amsterdam: IBFD, 2010. p. 21-50.

BECK, Ulrich. What is globalization? Cambridge: Polity, 2000.

BECKER, Helmut; WURM, Felix J. Survey. In: BECKER, Helmut; WURM, Felix J. (Org.). Treaty shopping: an emerging tax issue and its present status in various countries. Norwell: Kluwer Law, 1988. p. 1-8.

BENÍTEZ, Gloria Marín. El concepto de planificación fiscal agressiva en BEPS: una visión comparada de los conceptos de abuso de Derecho de la Unión y Decrecho español. In: CID, José Manuel Almudí; GUTIÉRREZ, Jorge Alberto Ferreras; GONZÁLEZ-BARREDA, Pablo Andres Hernández (Org.). El Plan de Acción sobre Erosión de Bases Imponibles y Traslado de Beneficios (BEPS): G-20, OCDE y Unión Europea. Cizur Menor (Navarra): Aranzadi, 2017. p. 85-108.

BRASIL. Decreto no 8.506, de 24 de agosto de 2015. Promulga o Acordo entre o Governo da República Federativa do Brasil e o Governo dos Estados Unidos da América para Melhoria da Observância Tributária Internacional e Implementação do FATCA, firmado em Brasília, em 23 de setembro de 2014. Presidência da República, Brasília, DF, 2015a. Disponível em: <https://www.planalto.gov.br/ccivil_03/_ato2015-2018/2015/decreto/d8506. htm>. Acesso em: 5 set. 2017.

Exposição de Motivos 0080 de 2015 à Media Provisória 685 de 2015. Brasília:

Presidência da República, 2015b. Disponível em: <http://www.planalto.gov.br/ccivil_03/_ 
Ato2015-2018/2015/Exm/Exm-MP\%20685-15.doc>. Acesso em: 15 ago. 2017.

Supremo Tribunal Federal. Recurso extraordinário no 601.314, de 24 de fevereiro de 2016. Relator: Edson Fachin, Tribunal Pleno, julgado em 24/2/2016, Acórdão Eletrônico Repercussão Geral - Mérito. DJe, n.198, 2016. Disponível em: <www.stf.jus.br/portal/ processo/verProcessoPeca.asp?id=310303477\& tipoApp=.pdf $>$. Acesso em: 15 ago. 2017.

Lei no 5.172, de 25 de outubro de 1966. Dispõe sobre o Sistema Tributário Nacional e institui normas gerais de direito tributário aplicáveis à União, Estados e Municípios. Presidência da República, Brasília, DF, 1966. Disponível em: <http://www.planalto.gov.br/CCivil_03/leis/L5172.htm>. Acesso em: 15 ago. 2017.

BYRNES, William; MUNRO, Robert J. Lexisnexis ${ }^{\circledR}$ Guide to FATCA Compliance: chapter 1. SSRN Scholarly Paper. 2016. Disponível em: <http://papers.ssrn.com/abstract=2742383>. Acesso em: 9 set. 2017.

DAVET, Gérard; LHOMME, Fabrice; MICHEL, Serge. "SwissLeaks »: the backstory of a worldwide investigation. Le Monde.fr, 2015. Disponível em: <http://www.lemonde. $\mathrm{fr} /$ evasion-fiscale/article/2015/02/08/swissleaks-the-backstory-of-a-worldwide-investigation_4572334_4862750.html>. Acesso em: 16 jan. 2018.

DIETSCH, Peter. Catching capital: the ethics of tax competition. New York: Oxford University Press, 2015.

DOURADO, Ana Paula. Direito Fiscal: lições. Coimbra: Almedina, 2016.

ESTADOS UNIDOS DA AMÉRICA. Foreign Account Tax Compliance Act (FATCA). 2017. Disponível em: <https://www.treasury.gov/resource-center/tax-policy/treaties/Pages/FATCA.aspx>. Acesso em: 13 jan. 2018.

EVERTSSON, Nubia. Corporate tax avoidance: a crime of globalization. Crime, Law and Social Change, v. 66, n. 2, p. 199-216, 2016.

FAULHABER, Lilian V. The trouble with tax competition: from practice to theory. Rochester, NY: Social Science Research Network, 2017. Disponível em: <https://papers. ssrn.com/abstract=2912477>. Acesso em: 12 jan. 2018.

FOLLONI, André; YAZBEK, Cristiano Lisboa. Eficiência Tributária do Estado e Retorno de Bem-Estar à Sociedade. Revista Opinião Jurídica, Fortaleza, v. 11, n. 15, p. 26-39, 2013.

FRANÇA, Conseil Constitutionnel. Décision n²016-741 DC du 8 décembre 2016. 2016. Disponível em: <http://www.conseil-constitutionnel.fr/conseil-constitutionnel/francais/les-decisions/acces-par-date/decisions-depuis-1959/2016/2016-741-dc/decision-n-2016-741-dc-du-8-decembre-2016.148310.html>. Acesso em: 15 jan. 2018. 
GONZÁLEZ-BARREDA, Pablo Andres Hernández. El alcance material y formal del Plan BEPS: viejos conocidos, nuevos amigos y la necessidade de un nuevo enfoque. In: CID, José Manuel Almudí; GUTIÉRREZ, Jorge Alberto Ferreras; GONZÁLEZ-BARREDA, Pablo Andres Hernández (Org.). El Plan de Acción sobre Erosión de Bases Imponibles y Traslado de Beneficios (BEPS): G-20, OCDE y Unión Europea. Cizur Menor (Navarra): Aranzadi, 2017. p. 37-66.

GRINBERG, Itai. The battle over taxing offshore accounts. UCLA Law Review, v. 60, p. 304-383, 2012.

Building Institutions for a globalized world: automatic information exchange. In: POGGE, Thomas; MEHTA, Krishen (Org.). Global Tax Fairness. Oxford: Oxford University Press, 2016. p. 14-30.

GUPTA, Avinash. The Foreign Account Tax Compliance Act (FATCA). In: GÜNTER, Oliver-Christoph; TÜCHLER, Nicole (Org.). Exchange of information for tax purposes. Viena: Linde Verlag, 2013. p. 221-239.

HENKIN, Louis. Constitutional Rights and Human Rights. Harvard Civil Rights-Civil Liberties Law Review, v. 13, n. 3, p. 593-632, 1978.

HOLMES, Stephen; SUNSTEIN, Cass R. The cost of rights: why liberty depends on taxes. New York: W. W. Norton \& Co., 1999.

JARACH, Dino. Finanzas Públicas y Derecho Tributario. 3. ed. Buenos Aires: Abeledo-Perrot, 2004.

KERZNER, David S.; CHODIKOFF, David W. International Tax Evasion in the Global Information Age. Toronto: Irwin Law, 2016.

KOFLER, Georg; PISTONE, Pasquale. General Report. In: KOFLER, Georg; MADURO, Miguel Poiares; PISTONE, Pasquale (Org.). Human rights and taxation in Europe and the world. Amsterdam: IBFD, 2011. p. 3-33.

MACHADO, Jonatas E. M.; COSTA, Paulo Nogueira. Manual de direito fiscal: perspectiva multinível. Coimbra: Almedina, 2016.

MCGEE, Robert W. Duty to Whom? In: MCGEE, Robert W. (Org.). The ethics of tax evasion: perspectives in theory and practice. New York: Springer, 2012. p. 35-45.

MOTA, Raquel Gonçalves. A cooperação internacional na operacionalização do intercâmbio de informações fiscais. In: NABAIS, José Casalta; SILVA, Suzana Tavares da (Org.).

Sustentabilidade Fiscal em Tempos de Crise. Coimbra: Almedina, 2011. p. 167-204.

NABAIS, José Casalta. Da Sustentabilidade do Estado Fiscal. In: NABAIS, José Casalta; SILVA, Suzana Tavares da (Org.). Sustentabilidade Fiscal em Tempos de Crise. Coimbra: Almedina, 2011. p. 11-59. 
ORGANISATION FOR ECONOMIC CO-OPERATION AND DEVELOPMENT. Explanatory Statement, OECD/G20 Base Erosion and Profit Shifting Project. Paris: OECD, 2015a. Disponível em: <http://www.oecd.org/ctp/beps-explanatory-statement-2015.pdf>. Acesso em: 15 ago. 2016.

. Mandatory Disclosure Rules, Action 12 - 2015 Final Report OECD/G20 Base Erosion and Profit Shifting Project. Paris: OECD, 2015b. Disponível em: <http:// www.oecd-ilibrary.org/docserver/download/2315371e.pdf?expires=1471269795\&id=id\&a ccname $=$ guest $\&$ checksum $=$ FD137CEB829EB609CF066B9D603BFDCC $>$. Acesso em: 15 ago. 2016.

Active with Brazil. 2015c. Disponível em: <http://www.oecd.org/brazil/Brazil\%2 ObrochureWEB.pdf>. Acesso em: 5 set. 2016.

Revenue Statistics in Latin America and the Caribbean 1990-2015. Paris:

OECD Publishing, 2017a. Disponível em: <http://www.keepeek.com/Digital-Asset-Management/oecd/taxation/revenue-statistics-in-latin-america-and-the-caribbean-2017_rev_lat_ car-2017-en-fr>. Acesso em: 4 jan. 2018.

Revenue Statistics - OECD countries: comparative tables. 2017b. Disponível em: <https://stats.oecd.org/Index.aspx?DataSetCode=REV>. Acesso em: 5 jan. 2018.

About the Inclusive Framework on BEPS. 2017c. Disponível em: <http://www. oecd.org/tax/beps/beps-about.htm>. Acesso em: 5 set. 2017.

Inclusive Framework on BEPS Progress report July 2016-June 2017. 2017d.

Disponível em: <http://www.oecd.org/tax/beps/inclusive-framework-on-BEPS-progress-report-july-2016-june-2017.pdf $>$. Acesso em: 11 jan. 2018.

PANKIV, Marta. Tax Information Exchange Agreements (TIEAS). In: GÜNTER, Oliver-Christoph; TÜCHLER, Nicole (Org.). Exchange of Information for Tax Purposes. Viena: Linde Verlag, 2013. p. 153-174.

POGGE, Thomas; MEHTA, Krishen. Introduction: the moral significance of tax-motivated outflows. In: POGGE, Thomas; MEHTA, Krishen (Org.). Global Tax Fairness. Oxford: Oxford University Press, 2016. p. 1-13.

PORTUGAL. Decreto do Presidente da República n. 53/2016. Diário da República, n. 150, Série I, 5 ago. 2016a. Disponível em: 〈https://dre.pt〉. Acesso em: 12 jan. 2018.

. Parecer $n^{\circ}$ 22/2016 da Comissão Nacional de Protecção de Dados. 2016b. Disponível em: 〈https://www.cnpd.pt/bin/decisoes/Par/40_22_2016.pdf〉. Acesso em: 6 set. 2016.

Ministério Das Finanças e da Administração. Decreto-lei 29/2008, de 25 de Fevereiro. 2008. Disponível em: <https://dre.tretas.org/dre/229553/decreto-lei-29-2008-de-25-de-fevereiro>. Acesso em: 13 jan. 2018. 
RANZ, Alfredo. Los deberes de revelación de estrategias de planificación fiscal agresiva. In: CID, José Manuel Almudí; GUTIÉRREZ, Jorge Alberto Ferreras; GONZÁLEZ-BARREDA, Pablo Andres Hernández (Org.). El Plan de Acción sobre Erosión de Bases Imponibles y Traslado de Beneficios (BEPS): G-20, OCDE y Unión Europea. Cizur Menor (Navarra): Aranzadi, 2017. p. 389-398.

RIXEN, Thomas. The Political Economy of International Tax Governance. New York: Palgrave Macmillan, 2008.

SANTOS, António Carlos; PALMA, Clotilde Celorico. Portugal. In: KRISTOFFERSON, Eleonor et al. (Org.). Tax secrecy and tax transparency: the relevance of confidentiality in tax law- part 1 and 2. Frankfurt am Main: Peter Lang GmbH, 2013. p. 851-885.

THOM, Michael. Tax politics and policy. New York: Routledge, 2017.

UNIÃO EUROPEIA. Tribunal de Justiça. Acórdão nos processos C-293/12 e C-594/12. 2014. Disponível em: <http://curia.europa.eu/juris/document/document. jsf?docid=150642\& doclang=PT>. Acesso em: 15 jan. 2018.

VASCONCELLOS, Stela Márcia Sales. Os paraísos fiscais e a evasão fiscal. Revista Opinião Jurídica, Fortaleza, v. 10, n. 14, p. 336-351, 2012. 